\title{
E.B. Kulman's Creative Work in the Context of the History of Russian Literature and Russian Poetic Translation
}

\author{
Dmitry Nikolayevich Zhatkin \\ Department of Translation and Methods of Translation, Penza State Technological University, \\ Baidukov Thoroughfare / Gagarin Street, 1a / 11, Penza, Russian Federation
}

Olga Sergeevna Milotaeva

Department of Foreign Languages of the Penza State University of Architecture and Construction, Penza, Russian Federation

\section{Doi:10.5901/mjss.2015.v6n3s3p139}

\begin{abstract}
In the article the facts of influence of German literature and art on the formation of a creative person of the Russian poetess and translator of the first third of the XIXth century E.B.Kulman are for the first time elicited, and also echoes of her creativity in German art culture of the subsequent time are systematized. The facts of the appeal of E.B.Kulman to the translations of works of antique authors, to free interpretations of the texts of I.-V.Goethe, I.-G. Foss, S.Gesner, etc., and also influence of the first edition of her "Poetic attempts" on the Russian literature are noted "imagination" in A.V.Timofeev's verses "Elizabeth Kulman", B.M.Fedorov's poem "To Elizabeth Kulman's portrait", etc.). As the most considerable event in posthumous history of E.B.Kulman's works is considered the appeal to them of the composer R. Schuman who created two vocal cycles in 1851 "Maiden songs" (op. 103, for two voices and a piano) and "Seven songs" (op. 104, for a voice and a piano). The special attention in the article is paid to a question of possible influence of E.B.Kulman's fairy tale "The fisherman and his wife" (along with the fairy tale of the same name of brothers Grimm) on A.S.Pushkin in the period of creation of "The tale of the fisherman and a small fish". In E.B.Kulman's fairy tale "The fisherman and his wife", as well as in the earlier work of brothers Grimm, heroes of the fairy tales - not so much characters, as elements of plot making; at A.S.Pushkin's work the plot becomes simpler and fantastic motives are filled with the lyrical contents, the accent is transferred from the plot to the general lyrical action, characters and pictures. The authors of the article for the first time establish community and distinctions in the text of three fantastic works, and in each text both traditions of national culture and poetry, and rich art world of the German and Russian writers are found. Finally in the article the considerable materials allowing to speak not only about a bilingualism of E.B.Kulman, but also about the development of her creativity on a joint of Russian and a number of West European cultures are generalized, the specified value of her creativity for the development of the Russian literary translation of the XIXth century, the Russian translated fiction, need of preparation of the scientific publication of works of E.B.Kulman which exit could become the beginning of a new stage in studying of works of the talented poetess is noted.
\end{abstract}

Keywords: E.B.Kulman, poetry, literary translation, international literary and historical and cultural relations, reminiscence, tradition, cross-cultural communication, comparative study, reception.

\section{Introduction}

To a name of Elizabeth Borisovna Kulman the native literary criticism appeals with enviable constancy, and by the way, the ambiguous estimates of her poetry are traditionally combined with recognition of exclusiveness of her linguistic phenomenon. Kulman's creative biography became one of the brightest pages in the history of Russian-German literary and cultural communications of the XIXth century.

From biographic sources it is known that Elizabeth Kulman came from a family of the hereditary German officers who were in Russia in the imperial service, and her father who early died was the participant of campaigns of P.A.Rumyantsev-Zadunaysky and A.V.Suvorov. Since the early childhood Kulman showed unusual abilities, comparable just with talents of young W.-A.Mozart. By ten years old she had been perfectly spoken Russian, German and French, soon she learned to speak fluent Italian, and then learned Latin, Greek, Church Slavonic, English, Spanish, Portuguese and modern Greek languages. Merits in Elizabeth's training in the German language entirely belonged to her mother that Karl Grossgeynrikh so remembered: "Madam Kulman knew German perfectly, and we have never heard a grammatical mistake in her expressions <...; Madam Kulman trained all her children herself, while they were under her supervision, 
and fulfilled this duty with rare integrity. In language training her first care was to make her children pronounce each word as distinctly and purely as possible; every time she corrected their mistakes, she accustomed them to the use always only of certain words for expression of the thoughts and at any case showed them distinction between similar expressions" (Grossgeynrikh, 1849).

Having found unusual abilities of Elizabeth Kulman, the family friend Karl Grosskgeynrikh who was well speaking many classic and modern languages started working hard with the girl, introduced some elements of literary creativity for her. First poems "Morning Prayer of a Raven" and "As breeze..." were written by Elizabeth in German at the age of eleven. The circle of reading of young Kulman in many respects was defined by Karl Grossgeynrikh's likings. From the writers creating their own works in German S.Gesner, K.-F.Gellert, H.-E.Kleyst, F.-G.Klopshtok, I.-V.-L.Gleym, I.-G.Foss, I.-G.Jacobi, and so on attracted Elizabeth more. Under the influence of Grossgeynrikh Elizabeth Kulman appealed in her creative works to the traditions of antiquity. She was impressed by an image of Corinna - the Ancient Greek poetess whose verses didn't remain, however, on a legend, made the worthy competition to Pindar's creative works. Grossgeynrikh suggested Elizabeth who had quite well studied the heritage of antique poets "to revive Corinna" - to write the original verses which could be given out then "for the right and fine translation of own compositions of Corinna which were found incidentally between manuscripts of the Greek monastery" (Grossgeynrikh, 1849). Thereby Grossgeynrikh declined the learner to the mystification similar to "Ossian's Songs" of J. McPherson. Kulman's "Corinna's Poems" won a fame of "Northern Corinna" (Rusakov, 1909). Kulman's last verses written at seventeen, shortly before her death, are full of foreseeing feeling of the end and inescapable, light grief ("Farewell to life", "To death", "Farewell of flowers").

\section{Literature Review}

During Elizabeth Kulman's lifetime it wasn't published any her work. Karl Grossgeynrikh sincerely convinced that the compositions of his learner will be interesting for Russian and European readers made a lot of efforts for publication of Kulman's works. The president of the Russian Academy admiral A.S.Shishkov helped him. He decided to publish poetic compositions of Kulman by means of the academy. The detailed biographic sketch to this edition was written by the graduate from a military department of Petersburg University A.V.Nikitenko who gave to Kulman's verses high appreciation: "Her poems are not essentially lyrical fragments where any feeling on a minute enthusiasm is expressed in several, thrown at random pictures. No! Each her play is a small poem, a harmonous, organic creation. You will not almost meet anywhere an idea which would be developed not in alive images. Besides you will be amazed by surprising completeness of images, distinctness and clarity in each line of painting" (Nikitenko, 1835). The edition which is carried out by the Russian Academy in 1833 with a circulation of 800 copies drew attention of many eminent persons of Russian literature. So, I. V. Kireevsky wrote on December 10, 1833 in "Odessky Vestnik"(" Odessa messenger") in the article "About the Russian Writers" that Kulman's works "will win one of the first prizes among the works of our ladies-poets" (Kireevsky, 1911).

E.B.Kulman was when her tutor Karl Grossgeynrikh made the hand-written collection of her poems in German, and also in Italian and French and sent it to Weimar to a friend with a request to show it to I.-V.Goethe. Soon the answer came from Weimar: the friend told Grossgeynrikh about the meeting with Goethe and transferred his words: "Declare to the young writer from me, Goethe, that I prophesy her an honor place in literature, in what kind of language she would write" (Grossgeynrikh, 1849). It is known that among works with which Goethe got acquainted, there was E.Kulman's "Frahlingslied" ("A spring song"): "Der Fruhling kehret wieder/Und schucket Berg und Thai; / Schon tonen rings die Lieder/Der stissen Nachtigal... / Wie steiget hoch die Sonne/Iris Him-melblau hinauf, / Verbreitet Lust und Wonne/Auf inrem breiten Lauf! / Es eilen Schaaf und Kinder/Der Greisfus seiner Ruh" (Munt-Valuyeva, 1896).

The enthusiastic review of Kulman and her creativity can be read in V.K.Kyukhelbeker's diary, and the note is dated on January 28, 1835: "Elisaveta Kulman - what a wonderful creature! - Her verses are the best of all ladies' ones that l've ever read in Russian, but she is still better than the verses $<\ldots>$ I won't leave $<\ldots>$ without gift of a sacred, virgin shadow of Elisa! What a pity that I didn't know her! There is no doubt that I would fall in love with her..." (Küchelbecker, 1979). To all appearances this diary note was made after reading of the sketch written by A.V.Nikiktenko and published in "Severnaya pchela"("Northern bee") or in "Biblioteka dlya chteniya"( "Library for reading") (Nikitenko, 1833; Nikitenko, 1835). January, 1835 was one of the most fruitful creative periods in life of Küchelbecker who was in single imprisonment in Sveaborgsky fortress. The poem "Elisaveta Kulman" written on January 29-30, 1835 finished this active period in the life of the poet. Drawing certain parallels between his tragic destiny and untimely death of the young poetess, Küchelbecker asked a rhetorical question: "Ah, whether for you, a celestial rose, / You have to blossom in a heavy haze, I In a murder frost?" (Küchelbecker, 1967). Kyukhelbeker's poem for the first time was published only in 1884 (Küchelbecker, 1884). 
A.V.Timofeev's "imagination" in verses "Elizabeth Kulman" published as a separate book (Timofeev, 1835) also became a response to the first edition "Piitichesky opyt"("Piety experience") (Timofeev, 1835). This "imagination" was soon translated by Karl Grossgeynrikh into German, however the sharp critical review on this work, sounded in V.G.Belinsky's article, gave up for lost not only the composition, but also all creative works of A.V.Timofeev (Belinsky, 1953). A bit later, in 1842, the poet B. M. Fedorov who anonymously published the poem "To Elisaveta Kulman's Portrait" in "Mayak"(" Beacon") responded to Kulman's verses (Fedorov, 1842).

Up to the present the objective historical and literary assessment of E.B.Kulman's poetry hasn't been given. The controversial, sometimes not corresponding to modern achievements of literary criticism characteristic features of poetess's works contain in E.S.Nekrasova and S.N.Durylin's articles (Nekrasova, 1886; Durylin, 1932; Durylin, 1937), written at the end of the XIXth - the first third of the XXth century. Scientists-philologists still should resolve an issue of the value of poetic heritage of Elizabeth Kulman, to carry out reprinting of the best from her works.

\section{Materials and Methods}

Served as the material for the analysis: texts of the original and translated works of E.B.Kulman in Russian and German; the works of antique and West European writers translated by E.B.Kulman to the Russian and German languages; the works of the Russian and West European literature correlated to E.B.Kulman's creative works in respect of continuity of literary traditions; the literary and critical publications considering E.B.Kulman's creative works in the context of the general development of Russian and world literature; epistolary, diary and memoirs sources.

Fundamental works of classics of comparative-historical literary criticism of A.N.Veselovsky (Veselovsky, 1896), V.M.Zhirmunsky (Zhirmunsky, 1966), M.P.Alekseev (Alekseev, 1983), Yu.D.Levin (Levin, 1985), R.Yu.Danilevsky (Danilevsky, 1981), researches in the field of history of poetic translation (G.R.Gachechiladze (Gachechiladze, 1972), E.G.Etkind (Etkind, 1973), P.M.Toper (Toper, 2001), etc.), linguistic theory of translation (A.V.Fyodorov (Fedorov, 1983), L.L.Nelyubin \& G.T.Hukhuni (Nelyubin \& Hukhuni, 2008), R.R.Tchaikovsky (Tchaikovsky, 1997), etc.), problems of interference of the Russian and foreign literature (A.A.Anikst (Anikst, 1980), A.B.Botnikova (Botnikova, 1977), D.N.Zhatkin (Zhatkin, 2005), etc.) became theoretical and methodological base of the research, allowed to reveal E.B.Kulman, to see the influence of foreign creativity and at the same time national originality in her works.

The foreign publications devoted to E.B.Kulman's creative works, in particular, the publication of pieces of music of R. Schuman with E.B.Kulman's words (Schuman, <1851a>; Schuman, <1851b>), E.Lamprecht's book (Lamprecht, 1867), O.Lossewa's article (Lossewa, 1993) published in 1993 in Mainz in the known collection "Schumann Forschungen", U.Mahlert's sketches (Mahlert, 1993) and I.Gramlich (Gramlich, 2000), the works of the Ukrainian researcher G.I.Ganzburg published in the homeland in the 1990s (Ganzburg, 1994; Ganzburg, 1997) and in Germany (Hansburg, 2005).

\section{Results}

The special page of a creative heritage of E.Kulman is made by her fairy tales as the sources for which both works of the Russian folklore, and literary texts of brothers Grimm, Che. Perrault served. From all fantastic heritage of Kulman as the most successful it is possible to consider "the Magic Icon lamp" which plot is borrowed from "Thousand and one night", and the "Prince Vasily Boguslaich" based on the Russian folklore. We should also pay attention to the "overseas" Kulman's fairy tale "The fisherman and his wife" as to a possible predecessor of A.S.Pushkin known on created in 1835 as "Tale of the fisherman and small fish".

The question of sources Pushkin's "Tales of the fisherman and a small fish" traditionally is represented debatable, and in different years among sources were called the fairy tale "Goldfish" from A.N.Afanasyev's collection, the fairy tale "Fisherman and His Wife" from the collection of brothers Grimm, her French, Polish, Swedish, Czechoslovak parallels, transposition of Grimm's fairy tale E.B.Kulman with the same name "Fisherman and His Wife", was considered the version disproved by L.N.Maykov and N.F.Sumtsov about transferring a plot to Pushkin by V.I.Dahl. S.A.Shults was made the hypothesis of the connection of Pushkin's fairy tale with the XXIst Feokrit's idyll "Fishermen" telling about two poor old men one of whom dreamed he hooked gold fish which didn't receive scientific confirmation having received thereby hope for wellbeing and wealth (Schulz, 2002).

By careful comparison of the texts of folklore fairy tales (including a fairy tale "Goldfish" from A.N.Afanasyev's collection) and Pushkin's fairy tale A.R.Volkov made a conclusion that all known folklore options directly or indirectly are "free translations" of Pushkin's "The tale of the fisherman and a small fish". Thus, undoubtedly avoided Pushkin's influence it is possible to consider only those options - in Russian or other language which are written down no later than 
1835, i.e. before the publication of "Tales of the Fisherman and Small Fish" (Pushkin, 1835). This condition is completely fulfilled by the fairy tale "Fisherman and His Wife" which was written by Runge in Pomeranian and in 1809 is told by Arnim to brothers Grimm who included it in 1812 in the collection. The second and, perhaps, the only Russian option we can consider Kulman's poetic fairy tale with the same name "Fisherman and His Wife" representing transposition of the text from the Grimm's collection. The German by origin, Kulman was brought up and created under tutoring of the German teacher K.K.Grossgeynrikh storing pure classical models of the German art.

N.I.Sazonov pointed to the possibility of acquaintance of Pushkin with Grimm's texts in 1855 (Sazonoff, 1855), however the documentary evidence was produced considerably after S.M.Bondi (Bondi, 1931) and M.K.Azadovsky (Azadovsky, 1936). In particular, S.M.Bondi found in the State public library named after V. I. Lenin in Moscow and published a rough option "Tales of the Fisherman and Small Fish" in 1931 in which after the verse "Sit down just in your sledge!" there is such an episode which is directly correlated to the Grimm's text: "The other week passes / His old woman became crazy again/ She odered to find her husband / The old man was brought to the old woman / The old woman says to the old man / That she doesn't want to be the free queen / That she wants to be Pope $|\langle\ldots\rangle|$ All right, she will be Pope / The old man came back to the old woman / [The monastery is in front of him] latin-/The monks / Sing a Latin mass / The Babylon tower is in front of him/ On the highest top / His old woman is sitting / The old man bowed to the old woman / And greeted her in a loud voice / Are you happy now?/ The silly old woman answers/ You are lieing / I am absolutely dissatisfied / I don't want to be Pope/ And want to be the sea empress" (Pushkin, 1949). M.K.Azadovsky, recognizing relevancy of Grimm's influence, noted the existence in the Pushkin's fairy tale and the Russian folklore traditions the emergence of which was caused by the influence on the poet of his nurse Arina Rodionovna Yakovleva. However it is necessary to take into account that fact that in notes of the fairy tales made by Pushkin from the nurse and other storytellers, this plot isn't present even in Pushkin's programs. At the same time Pushkin had in the library the collection of fairy tales of brothers Grimm published in 1830 translated into French (Modzalevsky, 1988), and among Pushkin's drawings the image of two male heads relating to 1833, the attributed T.G.Tsyavlovskaya as Jacob and Wilhelm Grimm's image remained (Tsyavlovskaya, 1980).

Unlike the Pushkin's fairy tale, the poetic fairy tale "Fisherman and Wife" created in 1824 by E.B.Kulman had a subtitle "overseas", unambiguously pointing to its source. In this regard it is interesting to establish the connection of two fairy tales as interpretations of a known Grimm's plot. S.N.Durylin for the first time paid attention to a certain connection of fairy tales of Pushkin and Kulman in the 1930s (Durylin, 1937), however neither S.N.Durylin, nor researchers of the subsequent time didn't carry out the detailed comparative analysis of two fantastic texts.

A.S.Pushkin was attracted by the possibility of national interpretation of the plot of the German fairy tale. In the Russian fairy tale tradition this story has usually other type: desires of the old man are granted by means of a wonderful penny, a magic tree, etc. At Pushkin, as at brothers Grimm and Kulman's works, the action is connected with a wonderful small fish the image of which, however, is a little transformed. If at Grimm's tale the miracles are made by the flounder fish, being the fascinated prince, at Kulman's work - "plotvitsa("small fry"), the bewitched prince" (the image close to Grimm's), at Pushkin's tale - a goldfish; thus the great Russian poet removes a sorcery element, allocating a small fish with ability "to say by a human voice". The central image is russified due to use of a diminutive-hypocoristic form of the name (a suffix "-k -"), and for designation of magic the epithet "gold" is used (a favourite epithet of Arina Rodionovna which, according to M.K.Azadovsky's words, she often used (Azadovsky, 1936)).

In all three works the characteristic fantastic beginning is used: "Once upon a time there was a fisherman with the wife ..." (Grimm) - "Once upon a time there was a fisherman with the wife ..." (Kulman) - "There lived an old man with the old woman ..." (A. Pushkin). The cumulative composition of fairy tales of Pushkin and Kulman is expressed by two significant elements - an exposition (the fisherman/the old man caught a small fry / a goldfish who asks to release her and promises to make any his desire true) and the repeated motive (the small fish carries out the desires of the wife/the old woman, except the last then takes away everything that was earlier granted). However contrary to Grimm's and Pushkin's texts, Kulman's fairy tale is noted by painful prolixity, vast descriptions in which one image is strung on another: "Once upon a time there was a fisherman with the wife / On a large lake /That lake along the shore/ls covered with reed /And low, among motley / Lying rocks, / Treeless and gentle / Overgrown with a grass, / Young islands, - I Creature of gradual / Casual water, / And wide rivers, / with not fast muddy moisture / Through the lake flowing ..." (Kulman, 1841).

It is necessary to emphasize that in Kulman's fairy tale unlike two others, the image of the wife is static, there is no motive of increase of the conflict between the heroes: the wife expresses desires, and the fisherman implicitly goes to the sea to ask a plotvitsa(a small fry). And till the last moment between them, as well as in the source fairy tale the matrimonial relations remain. The motive of mockery and violence over the old man entirely belongs to Pushkin, and it becomes the main contents of the fairy tale. 
The motive of discontent of the old woman amplifying in the process of execution of her desires doesn't find reflection in two other fairy tales where the fisherman addresses to a small fish with the same words and only avaricious remarks of the author allow to catch changes in mood of the hero: "The fisherman didn't want to go $\langle\ldots\rangle$. It was heavy on heart of the fisherman $\langle\ldots\rangle$. The fisherman went in confusion $\langle\ldots\rangle$. He came the sea, but to he was afraid $\langle\ldots\rangle$. "The little man , / Fish flounder in water, / Ilzebill, my wife, / Against my will sends me" (Grimm, 1987); "And it is cloudy, and at a slow pace / Not fast there was our fisherman $|<\ldots\rangle$ / In shivering voice $/ T 0$ the river inhabitant $\mid\langle\ldots\rangle /$ He said with

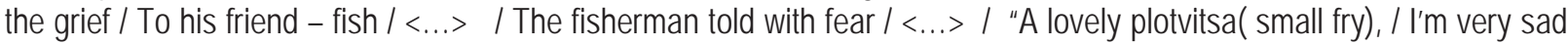
to disturb you / With a mad request! / But from the wife, believe me, / There is no rest, / Relieve me of boredom!" (Kulman,1841). As we can see, Kulman is very close to the German original. It is possible to see the other treatment of Pushkin: "Argued my old woman $|\langle\ldots\rangle|$ Even more the old woman quarrels $|\langle\ldots\rangle|$ The old woman is more crazy $\mid\langle\ldots\rangle$ I Again my old woman revolts / <... / What should I do with the damned woman?" (Pushkin, 1948). In Pushkin's fairy tale the anger of the old man turns into indignation that gives to the description a shade of social satire that isn't present neither in Kulman's fairy tale, nor in the German source. In draft option of Pushkin's work this social moment is emphasized even more strongly: "I am a madam, a noblewoman for you / And you are my quitrent peasant" (Pushkin, 1949) (Cf.: "How you dare to contradict me? I am an empress, and you are my husband ..." (Grimm, 1987)). If in fairy tales of brothers Grimm and Kulman the wife politely addresses to the fisherman - "husband", "hubby" (Grimm); "my darling friend", "my friend" (Kulman), - that the speech of the old woman in the Pushkin's fairy tale is characterized by roughness ("fool", "ninny"). Pushkin's satire is full of deep bitterness which is absent both in Kulman's texts and in Grimm's fairy tale.

The motive of increasing discontent of a small fish in many respects we correlate to the motive of gradual strengthening of sea excitement, to absolutely alien for Russian versions of fairy tales. At the same time Pushkin rather precisely recreates Grimm's pictures of the worrying sea: "the sea grew dull, darkened" (Grimm) - "the blue sea grew dull" (Pushkin), "the sea was excited, turned black, became pitch-dark" (Grimm) - "the blue sea isn't calm, the blue sea turned black" (Pushkin), "it was stormed, everything rustled and roared ..." (Grimm) - "at the sea a storm, and angry waves were blown up, and go, so howl and howl" (Pushkin). As we see, in the fairy tales the alive image of the sea which is symbolically representing the increasing anger of a small fish is created. However, following the traditions of the Russian national fairy tale, Pushkin introduces a new constant epithet which is absent in Grimm and Kulman's fairy tales - "the blue sea". Unlike the Grimm's description drawing terrible, gloomy pictures of the sea storm and excitement in a magic and fantastic way, Pushkin depicts the change of the sea as the "immemorial free elements" according to supervision of G.P.Makogonenko is as "objective reality" (Makogonenko, 1982).

A little in other regard the pictures of the changing water space are presented in Kulman's fairy tale. First, the image of the sea from the German fairy tale Kulman replaces with image of the lake; secondly, as the main tool for the changing nature pictures at Kulman's images are the clouds by means of which an increasing excitement of a plotvitsa (a small fry) is described whereas the lake is characterized every time by only one epithet which is metaphorical: "the lake motionless", "over the calm lake there are scattered clouds", "over the gloomy lake there are clouds", "over the angry lake there is a black rainy cloud", etc.

The plot of the German fairy tale is known under the binary name (the same in Kulman's option) "The fisherman and his wife". Pushkin, as though follows tradition, keeps binarity, however the name of the work hints at the noted above emphasis in a plot. And Pushkin shows a known opposition "a small fish - the fisherman and the wife" (as in Grimm and Kulman's fairy tales) by means of the title in other field offering opposition "a small fish, the fisherman - the old woman".

A form of work also distinguishes the compared fairy tales. Unlike brothers Grimm, Kulman and Pushkin state a plot poetically: Kulman - a blank verse, Pushkin - "three-shock with the female termination" (Zhirmunsky, 1977). Verses provide to the author considerably more freedom in the attitude towards "foreign" speech norms, than the prose, "and about alien the poet speaks in his native language" (Bakhtin, 1972).

\section{Discussion}

Nature of the last desire of the heroine has the differentiating symbolics in the fairy tales. At Kulman's tale the wife of the fisherman wants to become immortal ("I want to be immortal"), at Grimm's - she wants to become a god "to order the moon and the sun", at Pushkin's the old woman wishes to become "the sea empress" "to make the goldfish serve". In the German source and in Kulman's fairy tale the principle of the accruing expression reaches the apogee - the wife wishes that, more that can't already wish - divine power and immortality. Pushkin in his text reaches a culmination point within a social and satirical orientation, and in this regard boundary, unrestrained desire of the quarrelsome, insatiable old woman is freedom, in this case, of the goldfish. In the beginning, in a draft copy, the last desire of the old woman looked so: "And 
I want <to be> empresses of the sun" (Pushkin, 1949). Cf.: "I want to order the moon and the sun" in the text of the fairy tale of brothers Grimm. Desire, really, excessive, however not pushing together directly the heroine and the donator. In a final version of Pushkin's fairy tale the desire of the old woman mentioned above prepared for a small fish the old man's fate - "the obedient slave". He isn't a simple donator any more, it is not a function but it is a separate destiny. But if the old man, conscientious, understanding everything, - nevertheless obeyed, a small fish - no.

The final of fairy tales of brothers Grimm and Kulman strictly follows the law "no sooner said than done": together with a penalty the words about punishment sound - the action is fixed in the word: "So go home, she is sitting again on a threshold of the izba" (Grimm, 1987); "Well, all right, my savior! / Your wife, apparently, /ls not satisfied./And you go back I To your favourite hut $\mid<\ldots>$ / Your wife is already there" (Kulman, 1841). At Pushkin's work in a similar situation, as we know, everything is presented a little differently. It is curious that the poet came not at once to the decision - judging by draft copies, in the beginning he strictly followed folklore tradition: "The goldfish dived / Saying / Go both of you in a dugout / Splashed the tail on water / And dived" (Pushkin, 1949). These lines were replaced by others: "The small fish splashed on water by tail / And dived into the blue sea / the old man didn't wait for the answer / The old man turned back to the old woman" (Pushkin, 1949). At last, in a final version of the text the small fish disappears silently: "Nothing was told by the small fish, / Only a tail on water splashed / And went to the deep sea" (Pushkin, 1948). As we see, at Pushkin's work, unlike fairy tales Grimm and Kulman's fairy tales, the small fish in a final scene is silent: she can, is able, but doesn't want to speak. The direct speech at action can be omitted and in national fairy tales (then it is meant, conjectured). But Pushkin has something other, namely - the indication to absence of the speech of the character, switching in another narrative system.

Kulman's fairy tale according to S.N.Durylin is distinguished by the "poor scarcity of language" filled by "dense slavyanizms", "sad helplessness of a verse" (Durylin, 1937). Along with pleasant descriptions and popular language we can see illegible connections of the words ennobled with the simple quite often. If Pushkin states a known plot, in many respects following traditions of Russian national poetry, Kulman once again remains faithful to "the Greek style" in her works. However similarity of Pushkin's fairy tale and Kulman's fairy tale in the image of household details is represented interesting: clothes, furniture in rooms, etc., typical of the Russian folklore. For example: "brocade on a poppy-head a kichka" (Pushkin) - "big sleeves with a brocade border" (Kulman); "pearls loaded a neck" (Pushkin) - "an amber necklace of the wife" (Kulman); "... in chambers sees the old woman, / she sits at a table as the queen" (Pushkin) - "... where on a brilliant throne / the wife is sitting as the queen"(Kulman). Noted similarities have no documentary confirmed explanation. Pushkin wasn't familiar with the "overseas" fairy tale and Kulman, in turn, read from Pushkin only one "fairy tale" - the poem "Ruslan and Lyudmila". And therefore any comments can't be considered as reliable.

\section{Conclusions}

It is only possible to assume that, having addressed in 1824 to the Russian fairy tales and bylinas, the young poetess could acquire some characteristic features of the Russian folklore, though these assumptions can seem very doubtful. In Kulman's fairy tale "The fisherman and his wife", as well as in the German source, heroes of fairy tales - not so much characters, as elements of plot construction. At Pushkin's work the plot becomes simpler and fantastic motives are filled with the lyrical contents. Here the main thing not so much in a plot, as in the general lyrical action, in characters and pictures.

As we can see brothers Grimm's fairy tale "Fisherman and his wife" gave rich art material both for A.S. Pushkin and for E.B.Kulman. However, skillfully, gracefully the processed plot elements of the German fairy tale appear in imagination of a reader not at all as transpositions of Grimm's text, but as complete works of art where both traditions of national culture and poetry, and the rich art world of each poet found the expression.

It seemed the name of E.B.Kulman after her death in 1825 was strongly forgotten. But after a quarter of the century in 1851 there was a bright event - R. Schuman created on its verses two vocal cycles - "Maiden songs" (op. 103, for two voices and a piano) and "Seven songs" (op. 104, for a voice and a piano). That made in total eleven composite units (Lossewa, 1993; Loseva, 1996; Mahlert, 1993; Ganzburg, 1994; Ganzburg, 1997). The composer set the task to make the name of Kulman known about this he frankly told in "Dedication" to op. 104: "These modest songs are devoted to the memory of the girl which isn't present among us for a long time and which name is known not for everybody <...>. If these songs could make her name known in those numerous circles where about her still didn't hear, I would consider the purpose reached. I believe that the poetess who was familiar in the north only to some people three decades ago, will be met in Germany as a star sooner or later, and its shine will widely spread over all countries" (Schuman, 1969). Schuman's hope didn't come true: new musical interpretations of Kulman's creative works during the after Shumov period didn't follow. In many respects it can be explained that Kulman's verses haven't been republished for one and a half 
century. Thus preparation of the new edition of E.B.Kulman's works created in the Russian, German and Italian languages is actual nowadays; such edition (which is carried out, for example, within the Russian book series "New Library of the Poet") could give an impulse to the emergence of researches of the poetess works at a qualitatively new level.

\section{Acknowledgements}

The research has been carried out within the project on a grant of the Russian President of MD-5818.2015.6 "Textual criticism and poetics of the Russian literary translation of the XIXth - the beginning of the XXIst century: reception of English poetry of the Victorian era in synchronism and diachronism".

\section{References}

Alekseev, M.P. (1983). Comparative literary criticism. Leningrad: Science.

Anikst, A.A. (1980). The theory of drama in the West in the first half of the XIXth century. Moscow: Science.

Azadovsky, M.K. (1936). Sources of Pushkin's fairy tales. Vremennik of Pushkin's commission, II (pp.138-154). Moscow-Leningrad: State publishing house.

Bakhtin, M.M. (1972). The word in poetry and prose. Literature questions, 6. (pp. 73-98).

Belinsky, V.G. (1953). Songs of T. m. f. a. Part one. The second edition, added. St. Petersburg. Published in H.Gintsa's printing house. 1835; Elisaveta Kulman. Imagination. T. m f. a. St. Petersburg. Published in H.Gintsa's printing house. 1835. V.G.Belinsky. Complete works: In $13 \mathrm{v}$. Vol. 2. (pp. 76 - 82). Moscow: Publishing house of Academy of Sciences of the USSR.

Bondi, S.M. (1931). New pages of Pushkin. Articles, prose, letters. Moscow: World.

Botnikova, A.B. (1977). E.T.A.Hoffman and Russian literature (first half of the XIXth century). To a problem of Russian-German literary communications. Voronezh: Publishing house of Voronezh State University.

Danilevsky, R.Yu. (1981). German poems of the Russian poets. Multilingualism and literary creativity. Collection of scientific works (pp. 18-63). Leningrad: Science.

Durylin, S.N. (1932). The Russian writers at Goethe in Weimar. Literary inheritance, 3-4. (pp. 81-504). Moscow: Journal and newspaper association.

Durylin, S.N. (1937). Pushkin and Kulman. 30 days, 2. (pp. 87-91).

Etkind, E. G. (1973). Russian poets-translators from Trediakovskiy to Pushkin. Leningrad: Nauka (Science).

Fedorov, A.V. (1983). Art of the translation and the life of literature. Sketches. Leningrad: Soviet writer.

Fedorov, B.M. (1842). To Elisaveta Kulman's portrait. Beacon, I, II. (p. 91).

Gachechiladze, G.R. (1972). Literary translation and literary interrelations. Moscow: Soviet writer.

Ganzburg, G. I. (1994). Librettologiya and special aspects of studying of vocal works of F.Schubert and R.Schuman. Schubert and his works. Collection of materials of a scientific musicological symposium. (pp. 83-89). Kharkov: Institute of musicology.

Ganzburg, G.I. (1997). Characters of Schuman's song theater and their prototypes. Robert Schuman cross of ways of music and literature. Collection of scientific works. (pp. 19-26). Kharkov: Institute of musicology.

Gramlich, I. (2000). Auf den Spuren eines Engels: Zum 175. Todestag der deutsch-russischen Dichterin Elisabeth Kulmann. Volk auf dem Weg. Verbandszeitung der Landsmannschaft der Deutschen aus Rußland, 8/9, 42-45.

Grimm, Ya. \& Grimm, V. (1987). Fairy tales. Moscow: Truth.

Grossgeynrikh, K. (1849). Elisaveta Kulman and her poems. St. Petersburg: pr. Imperial educational house.

Hansburg, G. (2005). Aufsätze über Poetess Elisabeth Kulmann. Russland-Deutsche Zeitgeschichte unter Monarchie und Diktatur. Band 4. Herausgegeben von A.Bosch (ss. 76-127). Nürnberg-München: Grußburgwedel.

Kireevsky, I.V. (1911). About the Russian writers. I.V.Kireevsky Complete collection of works: In 2 v. Vol. 2. (pp. 61-78). M.: Way; pr. Imperial Moscow university.

Kulman, E.B. (1841). Piety experiences: In 3 ch. Ch. 3. (2nd ed.). St. Petersburg: printing house of Imperial Academy of Sciences.

Küchelbecker, V.K. (1884). Elisaveta Kulman. Russian old times, 2. (pp. 352-353).

Küchelbecker, V.K. (1967). Elisaveta Kulman.V.K.Küchelbecker. Chosen works: In 2 v. Vol. 1. (pp. 281-284). Moscow-Leningrad: Soviet writer.

Küchelbecker, V.K. (1979). Travel. Diary. Articles. Leningrad: Science.

Lamprecht, E. (1867). Elisabeth Kulmann. Biograph. Skizze. Mit Proben aus d. Gedichten. Zwickau: A. Chemnitz.

Levin, Yu.D. (1985). Russian translators of the XIXth century and development of a literary translation. Leningrad: Science.

Loseva, O.B. (1996). Monument to the poetess: Robert Schuman and Elizabeth Kulman. Russian-German musical communications. Ed. by I.I.Nikolskaya, Yu.N.Khokhlov (pp. 85-92). Moscow: State Institute of Art Studies.

Lossewa, O. (1993). Neues tiber Elisabeth Kulmann. Jn Schumann Forschungen. Bd. 4. Schumann und seine Dichter. Herausgegeben von M. Wendt (ss. 71-86). Mainz: Schott.

Mahlert, U. (1993). Die Spuren einer himmlischen Erscheinung zuriicklassend: zu Schumanns Liedern nach Gedichten von Elisabeth Kulmann op. 104. Jn Schumann in Dusseldorf: Werke, Texte, Interpretationen: Bericht tiber das 3. Internationale SchumannSymposion am 15 und 16 Juni 1988 in Rahmen des 3. Schumann-Festes, Dusseldorf. Herausgegeben von Berhard R. Appel (ss. 
79-97). Meinz-London: Schott.

Makogonenko, G.P. (1982). Pushkin's creative work in the 1830s (1833 - 1836). Leningrad: Soviet writer.

Modzalevsky, B.L. (1988). Pushkin's library. Moscow: Science.

Munt-Valuyeva, A.P. (1896). Not from this world. From the life of E.Kulman. St. Petersburg: pr. A.D.Stupina.

Nekrasova, E.S. (1886). Elizabeth Kulman. Historical bulletin, XXVI, 12. (pp. 551-560).

Nelyubin, L. L. \& Khukhuni, G. T. (2008). The science of translation (history and theory from ancient times to the present day). (2nd ed.). Moscow: Flinta; MPSI.

Nikitenko, A.V. (1833). Piety experience of E.Kulman. Northern bee. (p.239) (21 Oct.).

Nikitenko, A.V. (1835). Biography of the maiden Elisaveta Kulman. Library for reading, VIII, 12, I. (pp. 67-94).

Pushkin, A.S.. (1835). Tale of the fisherman and a small fish. Library for reading, XIII, 17, II. (pp. 17-23).

Pushkin, A.S. (1948). Tale of the fisherman and a small fish. A.S.Pushkin. Complete works: In 19 v. Vol. 3. Book 1. Poems. 1826-1836. Fairy tales (pp. 534-540). Moscow: Publishing house of Academy of Sciences of the USSR.

Pushkin, A.S. (1949). Tale of the fisherman and a small fish. <other options and editions> A.S. Pushkin. Complete works: In 19 v. Vol. 3. Book 2. Poems. 1826-1836. Fairy tales (pp. 1080-1089). Moscow: Publishing house of Academy of Sciences of the USSR.

Rusakov, V. <Librovich, S.F.> (1909). Russian Corinna. V.Rusakov. Well-known Russian girls. Biographical sketches (pp. 67-72). St.Petersburg-Moscow: edition of M.O. Wolf's Association.

Sazonoff, N. (1855). Contes populaires russes et allemanels. L' athenaeum francais. Revue universelle de la literature de la science et des beauxarts, 32, 685-687.

Schulz, S. A. (2002). Pushkin and Feokrit (once again to a question of a source of "Tale of the fisherman and a small fish"). Russian literature, 4. (pp. 124-127).

Schuman, R. (1969). Collection of vocal compositions. Vol. 5. Songs for a voice with a piano. Moscow: Soviet composer.

Schumann, R. (<1851a>). Mädchenlieder von Elisabeth Kulmann für 2 Sopran-St. jder Sopran u. Alt mit Begleitung des Pianoforte. Op. 103. Leipzig: Fr. Kistner.

Schumann, R. (<1851b>). Sieben Lieder von Elisabeth Kulmann zur Erinnerung an die Dichterin für eine Singstimme mit Begleitung des Pianoforte componirt von Rob. Schumann. Op.104. Leipzig: Fr. Kistner.

Tchaikovsky R.R. (1997). A poetic translation in a mirror of opinions. Magadan: Kordis.

Timofeev, A.V. (1835). Elizabeth Kulman. Imagination. St. Petersburg: printing house of H.Gints.

Toper, P.M. (2001). The translation in the system of comparative literary criticism. Moscow: Heritage.

Tsyavlovskaya, T.G. (1980). Pushkin's drawings. Moscow: Contemporary.

Veselovsky, A.N. (1896). The western influence in new Russian literature. Moscow: Russian association printing and publishing.

Zhatkin, D.N. (2005). A.A.Delwig's poetry and historico-literary traditions. Moscow: "Taganka" publishing house.

Zhirmunsky, V.M. (1966). Verse and translation. Russian-European literary communications (pp. 423-470). Leningrad: Nauka (Science).

Zhirmunsky, V.M. (1977). Theory of literature. Poetics. Stylistics. Leningrad: Science. 